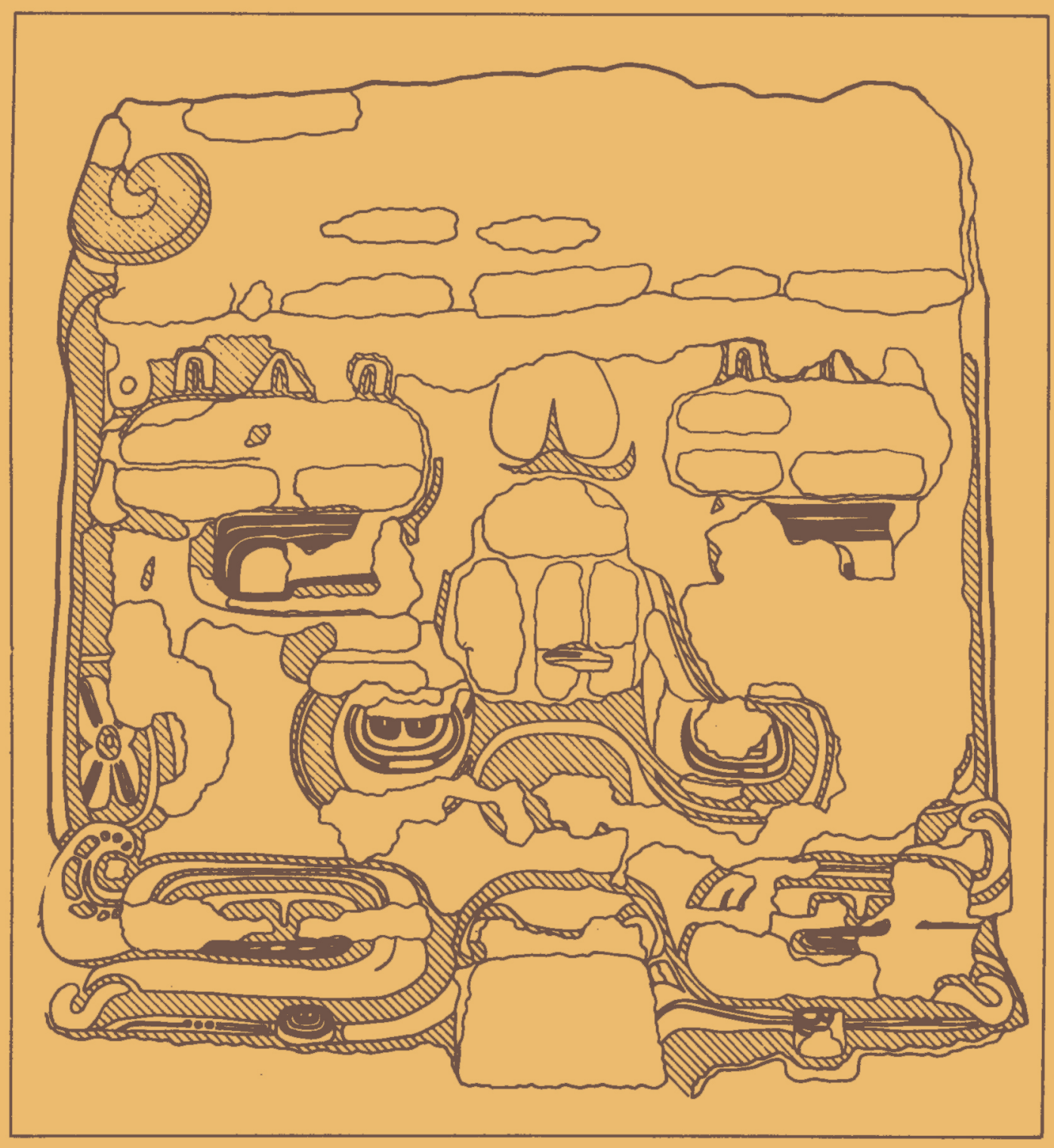

\title{
american antiquity
} JOURNAL OF THE SOCIETY FOR AMERICAN ARCHAEOLOGY

VOLUME 44 NUMBER 1

JANUARY 1979 


\title{
OFFICERS OF THE SOCIETY FOR AMERICAN ARCHAEOLOGY
}

President: Cynthia Irwin-Williams, Department of Anthropology, Eastern New Mexico University, Portales, NM 88130.

President-elect: FRED Wendorf, Department of Anthropology, Southern Methodist University, Dallas, TX 75222.

Secretary: Alfred E. Johnson, Museum of Anthropology, Blake Annex A, University of Kansas, Lawrence, KS 66045.

Treasurer: JEFFREY S. DEAN, Laboratory of Tree-Ring Research, Building No. 58, University of Arizona, Tucson, AZ 85721.

Editor: JEREMY A. SABLoff, Department of Anthropology; University of New Mexico, Albuquerque, NM 87131.

Executive Committee Members: George F. MacDonald, Archaeological Survey of Canada, National Museum of Man, National Museums of Canada, Ottawa, Ontario K1A OM8, Canada; William D. LIPE, Laboratory of Anthropology, Washington State University, Pullman, WA 99164; DAvid A. Breternitz, Department of Anthropology, University of Colorado, Boulder, CO 80309; ERnestene L. GReEN, U.S. Forest Service, 1720 Peachtree Street, N.W., Room 820, Atlanta, GA 30309.

\section{EDITORIAL STAFF OF AMERICAN ANTIQUITY}

Editor: Jeremy A. SABloff, Department of Anthropology, University of New Mexico, Albuquerque, NM 87131.

Associate Editor for Reviews: Ezra ZuBrow, Department of Anthropology, Spaulding Hall, Ellicott Complex, SUNY at Buffalo, Amherst, NY 14226.

Associate Editor for Current Research: THOMAs P. MYERs, University of Nebraska State Museum, 14th and U Streets, Lincoln, NE 68506.

Associate Editor for Current Affairs: Charles R. McGimsey III, Department of Anthropology, University of Arkansas, Fayetteville, AR 72701.

Assistant Editor: Lynne Sebastian.

\section{Production StafF \\ Production Manager: MARY MARTIN ROGERs. \\ Production Editor: TRUdY KAPLAN. \\ Circulation Manager: RUTH E. THORNTON.}

\begin{abstract}
American Antiquity publishes original papers on the archaeology of the New World and closely related subjects. Articles, Reports, and Comments should be submitted to the Editor, publications for review to the Associate Editor for Reviews, and information for "Current Research" to the Associate Editor for Current Research. American Antiquity is not available for exchange.

American Antiquity is published quarterly in January, April, July, and October by the Society for American Archaeology. Second-class postage paid at Washington, D.C. and additional mailing offices. Subscription is by membership in the Society for American Archaeology. Annual dues for individual members are $\$ 20.00$; for institutional members, $\$ 30.00$; for students, $\$ 12.00$; for foreign members, $\$ 16.00$. Annual membership dues include $\$ 4.00$ for a subscription to American Antiquity. Spouses of members are eligible for joint membership at $\$ 4.00$ per year (subscription to American Antiquity not included). Address requests for individual or institutional membership, instructions for change of address, ordering back issues, or complaints about subscription fulfillment to Society for American Archaeology, 1703 New Hampshire Avenue, N.W., Washington DC 20009. Copyright (c) 1979 by the Society for American Archaeology. All rights reserved. Printed in U.S.A.
\end{abstract}

\section{NOTICE TO AUTHORS}

Authors should submit an original and two copies of their manuscript. A detailed guide to all stylistic and technical questions can be found at the end of this issue. 


\title{
american antiquity
}

\author{
VOLUME 44 NUMBER 1 \\ JANUARY 1979
}

Jeremy A. Sabloff, Editor

Associate Editors: Ezra Zubrow (Reviews), Thomas P. Myers (Current Research), Charles R. McGimsey III (Current Affairs)

Assistant Editor: Lynne Sebastian

EDITOR'S CORNER

\section{CONTENTS}

The Decline and Rise of Mesopotamian Civilization:

An Ethnoarchaeological Perspective on the Evolution of

Social Complexity

Culture Areas and Interaction Spheres:

Contrasting Approaches to the Emergence of

Civilization in the Maya Lowlands

Routes: Alternate Migration Corridors for Early

Man in North America

An Economic Evaluation of the Potential of Fish

Utilization in Riverine Environments

Jeremy A. Sabloff

REPORTS

The Analysis and Distribution of Volcanic Ash-

Tempered Pottery in the Lowland Maya Area

The Earliest Lowland Maya: Definition of the Swasey Phase

Michael P. Simmons and Gerald F. Brem Norman Hammond, Duncan Pring,

Norman Yoffee

David A. Freidel 36

K. R. Fladmark 55

W. Frederick Limp and Van A. Reidhead 70 Elizabeth S. Wing, Arlene V. Miller, and Lawrence H. Feldman

The Aztec Marketing System and Settlement Pattern in the

Valley of Mexico: A Central Place Analysis

Michael E. Smith

Turrialba: A Paleoindian Quarry and Workshop Site in Eastern Costa Rica

Early Watertable Farming on the North Coast of Peru

Largo-Gallina Towers: An Explanation

Measuring the Selective Utilization of Animal Species

by Prehistoric Human Populations

Michael J. Snarskis Michael West

James Mackey and R.C. Green

CULTURAL RESOURCE MANAGEMENT

The Role of Museums in Cultural Resource Management

Bruce D. Smith

\section{CURRENT AFFAIRS COMMENTARY}

Andrew L. Christenson

161

Bennie Keel

\section{COMMENTS}

How to Succeed in Seriation Without Really Trying

Regional Subsampling and Statistical Inference in Forested Habitats

Robert D. Drennan 


\section{REVIEWS}

Logan: Woodland Complexes in Northeastern Iowa; Stothers: The Princess Point Complex

Frison: Prehistoric Hunters of the High Plains

Funk and Hayes III (editors): Current Perspectives in Northeastern Archaeology: Essays in Honor of William A. Ritchie

Zimmerman: Prehistoric Locational Behavior: A Computer Simulation

Denevan (editor): The Native Population of the Americas in 1492

Yellen: Archaeological Approaches to the Present: Models for Reconstructing the Past

Ingersoll, Yellen, and MacDonald (editors): Experimental Archeology

Kidney: Working Places: The Adaptive Use of Industrial Buildings;

Teague and Shenk: Excavations at Harmony Borax Works: Historical Archaeology

at Death Valley National Monument; Hickman: Country Nodes: An Anthropological

Evaluation of William Keys' Desert Queen Ranch, Joshua Tree National Monument, California

Zaslow and Dittert, Jr.: Pattern Mathematics and Archaeology

Frederick J. E. Gorman 188

Campbell: The Upper Palaeolithic of Britain

Dorothy K. Washburn 190

Brian Fagan 192

AMERICAN ANTIQUITY STYLE GUIDE 